\title{
Therapeutic potential of hydrolysable tannin on weight management oxidative stress and reproductive health in polycystic rats
}

\author{
Faiza MANZOOR ${ }^{1 *}$ (D), Mahr UN NISA ${ }^{1}$, Hafiz Amjad HUSSAIN ${ }^{2}$, Haseeb ANWAR ${ }^{3}$, Nazir AHMAD ${ }^{1}$, \\ Huma UMBREEN ${ }^{1}$
}

\begin{abstract}
Phytonutrients get attention now days due to their wide application and their tendency to improve the productive and reproductive performance in humans. Hydrolysable tannin (HT) is one of these bionutrients. The present study was aimed to investigate the therapeutic effect of HT on the induced polycystic ovarian syndrome (PCOS) in rats. Forty-five adult female rats with 4 to 5 days regular estrous cycle were selected. The PCOS was induced by a single intramuscular injection of Estradiol Valerate $4 \mathrm{mg} / \mathrm{rat} / \mathrm{kg}$. The rats were offered $0.5,1,1.5$ and $2 \%$ of HT/ $\mathrm{kg}$ body weight through oral gavage for two months. The results had shown a reduction $(\mathrm{p}<0.05)$ in average feed intake, body weight and weight gain, total oxidative stress and nutrient digestibility in PCOS rats. Similar reduction trend $(\mathrm{p}<0.05)$ in serum luteinizing hormone and insulin was observed; while serum follicular stimulating hormone, serum prolactin and total antioxidant capacity were improved $(\mathrm{p}<0.05)$. The ovarian histopathology showed no signs of reduction in cystic follicles while no improvement was observed in healthy follicles. The study concluded that the treatment with $1.5 \%$ level of HT had shown the best therapeutic potential for weight management, reduction of oxidative stress and improvement in reproductive health of PCOS rats.
\end{abstract}

Keywords: polycystic ovarian syndrome; hydrolysable tannin; reproductive hormones; oxidative stress; histopathology.

Practical Application: Hydrolysable tannin, a phytoneutrient could be used as an herbal remedy for the treatment of PCOS.

\section{Introduction}

Polycystic ovarian syndrome (PCOS) is the emerging infertility disease now a days but its severity varies in different societies due to their eating behavior and living style (Anbu et al., 2016). The PCOS is a complex metabolic and endocrinal disorder that affects both animals and women in their reproductive phases and increases the risk of reproductive abnormalities. The characteristic features of this disease are obesity, hyperglycemia, hyper-androgenism, an-ovulation, insulin resistance, dyslipidemia. In PCOS patients, an increased level of luteinizing hormone (LH), a decreased follicle stimulating hormone (FSH) and high LH/FSH ratio was observed. The formation of the small antral follicles and the development of multiple cystic ovaries were also the major features of PCOS patients (Çınar \& Gün Eryllmaz, 2016). The production of reactive oxygen species (ROS) is considered as one of the causative mechanisms behind infertility disorders which results the condition called oxidative stress (OS) (Sadoughi et al., 2017).

These hormonal disorders as well as OS were also due to diet, use of drugs, unhealthy life style and environmental factors (Andriyas \& Lal, 2013; Roychoudhury et al., 2017). The conventional therapies for the treatment of PCOS may have many side effects. Therefore, it is necessary to use biologically active botanical substances for infertility issues. A lot of research trials have been performed to find out the treatment of PCOS with medicinal plants and their functional compounds since ancient times (Sharma et al., 2013).

The hydrolysable tannin (HT) is one of the plants bioactive compounds (Buzzini et al., 2008). It possesses many health promoting activities like anti-obesity, anti-diabetic (Velayutham et al., 2012; Manzoor et al., 2020). The HT is potentially toxic to animals and shows some anti-nutritional properties as well. It disturbed the nutrient digestibility and helped to reduce feed intake in rats (Dawson et al., 1999; Ekambaram et al., 2018). The reduction in the voluntary feed intake might depend on the quantity of tannin, its molecular weight and physiology of the consuming animal (Hagerman et al., 1992) which exerted negative effects on the body weight of the rats (Hsu \& Yen, 2007). So, the previous studies had proved that HT had both healthy as well as negative effects on the rats. Therefore, the present study was planned to evaluate its healthy effects on weight management, oxidative stress, reproductive health and ovarian histology in PCOS rats.

\section{Materials and methods}

\subsection{Chemicals and material}

The experimental supplement HT was sponsored by the Diversified Marketing Group (DMG), Rawalpindi and the 
Estradiol Valerate tablets (Progynova) were purchased from the local medical market of Faisalabad. The kits were purchased from Bio-Rays chemical dealer near Allied Hospital Faisalabad. Feed ingredients were sponsored by Mukhtar Feeds and Rafhan Maize Products, Faisalabad, Pakistan.

\subsection{Study design}

In this study, forty-five adult female Albino rats ( 7 to 8 weeks old, weighed $135 \pm 5$ grams) were selected. They were kept in metabolic cages at $25 \pm 1{ }^{\circ} \mathrm{C}$ temperature and 45 to $55 \%$ of humidity with 12-hour light/dark cycle (Amini et al., 2016) in the animal house of Department of Pharmacology, Government College University (GCUF) Faisalabad, Pakistan. The study was approved by the Directorate of Advanced Studies, GCUF Faisalabad. All procedures had been performed according to the guidelines for the Care and Management of the Laboratory Animals (National Research Council, 1995). The total duration of this study was of 120 days, out of which 60 days were for rats' adjustment for diet acceptability and the induction of PCOS and other 60 days were for HT treatment and sample collection period.

\subsection{Polycystic induction}

All the forty-five female rats were placed on the same stages of their sexual cycle before the start of the trial. The rats were observed daily for seven consecutive days through visual methods as described by Byers et al. (2012) in order to evaluate their regular estrous stages. Then the rats with a regular estrous cycle of 4 to 5 days were selected. The initial body weight and blood glucose levels Accu-Check glucometer, Bayer of each rat were taken. A single dose of estradiol tablets was crushed $(4 \mathrm{mg} / \mathrm{rat} / \mathrm{kg})$ and dissolved in distilled water and was given through intramuscular injection for PCOS induction (Amini et al., 2016; Nofal et al., 2019). The rats were then observed daily with visual method until the signs of the irregular estrous cycle appeared. In PCOS condition the level of testosterone was increased due to which incidence of estrous phase or its duration was very less and the rats were shown persistent di-estrous phase (Anbu et al., 2016). To confirm the PCOS, the vaginal smear test was performed at the start of the $6^{\text {th }}$ week of estradiol injection (Ghafurniyan et al., 2015). Other signs of PCOS were also observed including their weight gain and fasting blood glucose levels $>200 \mathrm{mg} / \mathrm{dL}$ (Zhai et al., 2012; Ghasemzadeh et al., 2013).

\subsection{Experimental design}

At the $6^{\text {th }}$ week after the confirmation of PCOS, all the 45 rats were then divided into a completely randomized design of 5 equal groups $(n=9)$ and were offered different levels of $\mathrm{HT}$ as PC0.5: with $0.5 \% \mathrm{HT}$; PC1: with $1 \% \mathrm{HT}$; PC1.5: with $1.5 \%$ HT; PC2: with $2 \%$ HT while PC0: with $0 \%$ HT and called control. Group identification marks were given to each rat according to the method described by Silverman et al. (2014). The following formula was used for the calculation of HT dose (per kg bodyweight of rats/day).

Dosage $(\mathrm{mg})=$ Body weight of the rat $(\mathrm{g}) / 1000 \mathrm{~g} \times$ dose $(\mathrm{mg})$ (Erhirhie et al., 2014). The four calculated levels of HT were dissolved in warm water to prepare their respective solutions (Bonelli et al., 2018) and given through oral gavage once in a day for 60 days.

\subsection{Digestibility analysis}

During the 60 days collection period, the measurement of feed given to each group (split and leftover feed) was collected, weighed and recorded on daily basis to measure the daily feed consumed; while in the last seven days of the study, the feces samples were collected, weighed and recorded daily and pooled in tight plastic jars and stored at $-20^{\circ} \mathrm{C}$ for the digestibility analysis. The proximate analysis of feed and feces were done according to the Official Method of Analysis Chemists (Association of Official Analytical Chemists, 1990). For the determination of dry matter (DM) contents, the samples were dried at $105^{\circ} \mathrm{C}$ for 48 hours in a hot air oven; Muffle Furnace was used for the determination of ash contents by incineration of the samples at $550{ }^{\circ} \mathrm{C}$ for 4 hours; Petroleum Ether extraction (EE) method was used for the determination of crude fat contents. The digestion method $\left(\mathrm{H}_{2} \mathrm{SO}_{4}+\mathrm{NaOH}\right)$ was used for the determination of crude fiber (CF) and crude protein (CP) was determined by Kjeldahl Method. Nitrogen free extract (carbohydrate) was calculated by using the following Formula 1 (Adenike, 2013):

Carbohydrate $(\% N F E)=100-\left(\begin{array}{l}\% \text { moisture }+\% \text { ether extract }+ \\ \% \text { crude protein }+\% \text { ash }+\% \text { crude fiber }\end{array}\right)$

Digestibility was measured by total collection method using Formula 2 (Shi et al., 2015):

Nutrient Digestibility $(\%)=\frac{\text { Nutrient intake }(\mathrm{g} / \mathrm{kg})-\text { Nutrient in feces }(\mathrm{g} / \mathrm{kg}) \times 100}{\text { Nutrient intake }(\mathrm{g} / \mathrm{kg})}$

Body weight gain $(\mathrm{g})$ was calculated $=$ Final weight $(\mathrm{g})$ - Initial weight (g) (Ramachandran et al., 2020).

\subsection{Experimental diet}

The rats were fed basal diet ad libitum (Reeves et al., 1993; Manzoor et al., 2021) shown in Table 1.

\subsection{Biochemical analysis}

After overnight (12 hours) fasting, the rats were sacrificed early in the morning using chloroform for anesthesia. Blood samples were collected into the test tubes and allowed to clot. The serum had been separated by centrifugation at $5000 \mathrm{rpm}$ for $20 \mathrm{~min}$ and stored at $-20^{\circ} \mathrm{C}$ for biochemical analysis. Serum follicle-stimulating hormone, prolactin, progesterone and testosterone were analyzed by Radioimmunoassay (RIA; Gamma Counter). Serum luteinizing hormone, serum estrogen and serum insulin were analyzed by enzyme-linked immunesorbent assay (ELIZA; Eliza Reader). Erel Method was used for the determination of total antioxidant capacity (Erel, 2004) and total oxidative stress (Erel, 2005) and analyzed by micro-plate spectrophotometer (Bio-lab 310).

\subsection{Histological examination of ovarian tissues}

Following the procedure of Slaoui \& Fiette (2011), the ovarian tissues were removed and put in buffer formalin (10\%) and embedded in paraffin wax. 5-micron thick part (slice) arranged which was stained with Hematoxylin and Eosin. 
Stained horizontal sections were observed under a microscope (XSZ 107BN) for the evaluation of any histopathological changes. The evaluation of the ovarian histological and pathological changes was performed by an Associate professor of Pathology, Allied Hospital Faisalabad.

\subsection{Statistical analysis}

The statistically significant differences were evaluated by ANOVA using IBM SPSS statistics 21 (USA). All data were expressed as the Mean \pm SEM and the difference was considered significant at $p$-value $<0.05$.

\section{Results and discussion}

After the 60 days of HT intake, the results of average feed intake (FI), body weight (BW) and weight gain (BWG) of PC0 and PC0.5, PC1, PC1.5 and PC2 are presented in Table 2. After the PCOS induction, the $\mathrm{PC} 0$ had shown a significant increase $(\mathrm{p}<0.05)$ in FI, BWG and BW. After the oral intake of HT, the average FI, BWG and BW were decreased $(\mathrm{p}<0.05)$ in the PC2 as compared to PC1.5, PC1, PC0.5 and PC0 (Supplementary Material FD1). Dawson et al. (1999) reported that HT exhibited some anti-nutritional properties which reduced the animal body weight. As weight gain was frequently associated with PCOS

Table 1. Diet Composition (g/kg) and Nutrient levels on Dry Matter (DM) Basis (\%).

\begin{tabular}{lc}
\hline \multicolumn{1}{c}{ Ingredients } & Amount $(\mathrm{g} / \mathrm{kg})$ \\
\hline Corn Starch & 230 \\
Maltodextrine & 100 \\
Sucrose & 100 \\
Soya Bean Meal & 420 \\
Maize Bran & 50 \\
Soybean oil & 50 \\
Methionine & 3 \\
AIN 93G Vit Mix & 10 \\
AIN 93G Min Mix & 35 \\
Choline Bitartarate & 2 \\
Total Calories (kcal) & 3822 \\
Composition of Diet (g/kg) on Dry Matter basis (\%) \\
Dry Matter & 88.9 \\
Moisture & 11.1 \\
Ash & 8.3 \\
Crude Fat & 5.5 \\
Crude Fiber & 6.5 \\
Crude Protein & 18.6 \\
Nitrogen Free Extract & 50 \\
\hline
\end{tabular}

while the standard treatment of the patients ranged from the use of drugs to lifestyle modification which included changes in feeding habits and weight loss (Bency Baby et al., 2016). So the present results showed that the treatment with $1.5 \%$ and $2 \%$ levels of HT helped to decrease body weight and body weight gain in rats. The possible mechanism for decrease in intake was due to poor digestion of dry matter which impaired the emptying of digestive tract and resulted in weight loss. The second proposed mechanism that $\mathrm{HT}$ also acted as antioxidant might be another reason to decrease in body weight by increasing the antioxidant capacity (Hsu \& Yen, 2007; Manzoor et al. 2020).

Next the effect on nutrient digestibility in PCOS rats fed different levels of HT in different groups is shown in Figure 1 and Supplementary Material FD1. The percentage digestibility of dry matter (DM), crude protein (CP), ether extract (EE) and nitrogen free extract (NFE) had shown significant reduction in PC 1.5 and PC2 ( $<<0.05)$ as compared to PC1, PC0.5 and PC0. A non-significant improvement $(\mathrm{P}>0.05)$ was observed in the digestibility of crude fiber contents of all the treatment groups as compared to PC0. The digestibility of ash in PC1, PC1.5 and PC2 was improved $(\mathrm{p}<0.05)$ as compared to PC0.5 and PC0. The possible reason, that tannin reduced protein digestion by inhibiting the digestive enzymes because it formed a tanninprotein complex that was resistant to microbial degradation and increased the flow of protein towards the small intestine and resulted in weight loss (Bravo et al., 1992). However, $2 \%$ level of HT decreased the digestibility of fats and carbohydrates and mild improvement in the digestibility of ash while there was no effect on digestibility of fiber which was also reported previously (Bravo et al., 1994; Dalle Zotte \& Elena Cossu, 2009). The digestive enzymes were the first and the only enzymes that were exposed to the dietary tannin when food was consumed while; the decrease in the digestion of carbohydrates was also observed when the activity of starch digestive enzymes was inhibited by forming complexes with tannin (Carmona et al., 1996). So the digestive tract was assumed to be a site of the anti-nutritional effects of tannin. Another possible mechanism of decreased nutrient digestibility was due to the changes involved in the permeability of the intestinal wall. As a result of this reaction between HT and the membrane protein of the intestinal mucosal cells, there appeared less nutrient absorption (Dawson et al., 1999).

The statistical results of serum insulin and reproductive hormones in PCOS rats are presented in Table 3. The serum levels of insulin, LH and testosterone were increased significantly while FSH, estrogen and progesterone were decreased significantly $(\mathrm{p}<0.01)$ in the PC0 as compared to NC (Manzoor et al., 2020) as also confirmed in previous findings (Çınar \& Gün

Table 2. Average Feed Intake, Body weight and Body weight gain of PCOS Rats.

\begin{tabular}{|c|c|c|c|c|c|}
\hline Groups & PC0 & PC0.5 & PC1 & PC1.5 & PC2 \\
\hline Average Feed Intake (g) & $22.02 \pm 0.01^{\mathrm{a}}$ & $22.01 \pm 0.03^{\mathrm{a}}$ & $21.96 \pm 0.04^{\mathrm{b}}$ & $21.92 \pm 0.05^{\mathrm{b}}$ & $21.86 \pm 0.06^{\mathrm{b}}$ \\
\hline Initial Body Weight (g) (Before HT Treatment) & $149.24 \pm 3.75^{\mathrm{a}}$ & $148.20 \pm 2.33^{c}$ & $148.78 \pm 2.84^{\mathrm{b}}$ & $148.89 \pm 4.01^{\mathrm{b}}$ & $148.96 \pm 2.09^{\mathrm{b}}$ \\
\hline $\begin{array}{l}\text { Average Body Weight (g) (After } 60 \text { days } \\
\text { treatment) }\end{array}$ & $157.63 \pm 1.33^{\mathrm{a}}$ & $156.61 \pm 1.16^{\mathrm{ab}}$ & $154.83 \pm 0.96^{\mathrm{b}}$ & $154.46 \pm 1.20^{\mathrm{bc}}$ & $153.83 \pm 0.90^{c}$ \\
\hline Average Body Weight Gain (g) & $17.75 \pm 0.445^{\mathrm{a}}$ & $15.90 \pm 0.465^{\mathrm{b}}$ & $10.14 \pm 0.095^{\mathrm{c}}$ & $9.71 \pm 0.118^{c}$ & $7.99 \pm 0.055^{\mathrm{dw}}$ \\
\hline
\end{tabular}




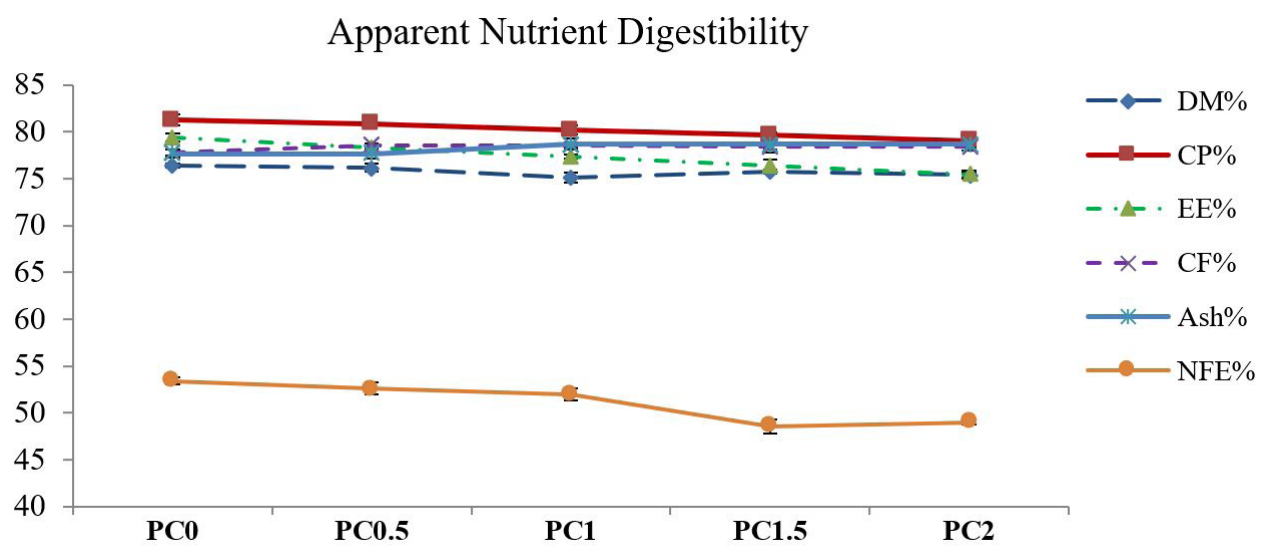

Figure 1. Apparent Nutrient Digestibility of PCOS Rats.

Table 3. Serum Insulin and Reproductive Hormonal Profile of PCOS Rats.

\begin{tabular}{|c|c|c|c|c|c|c|}
\hline Groups & $\mathrm{NC}$ & $\mathrm{PC} 0$ & PC 0.5 & PC1 & PC1.5 & $\mathrm{PC} 2$ \\
\hline Insulin $(\mu \mathrm{lU} / \mathrm{mL})$ & $15.01 \pm 0.16^{\mathrm{d}}$ & $15.67 \pm 0.28^{\mathrm{a}}$ & $15.57 \pm 0.12^{\mathrm{a}}$ & $14.50 \pm 0.13^{c}$ & $14.42 \pm 0.23^{c}$ & $15.21 \pm 0.20^{\mathrm{b}}$ \\
\hline $\mathrm{LH}(\mathrm{mlU} / \mathrm{mL})$ & $1.54 \pm 0.01^{\mathrm{c}}$ & $2.68 \pm 0.03^{\mathrm{a}}$ & $2.67 \pm 0.03^{\mathrm{a}}$ & $2.24 \pm 0.18^{\mathrm{ab}}$ & $1.96 \pm 0.17^{\mathrm{b}}$ & $2.02 \pm 0.12^{\mathrm{b}}$ \\
\hline $\mathrm{FSH}(\mathrm{mIU} / \mathrm{mL})$ & $2.56 \pm 0.00^{\mathrm{a}}$ & $2.20 \pm 0.03^{c}$ & $2.27 \pm 0.04^{\mathrm{bc}}$ & $2.32 \pm 0.05^{\mathrm{b}}$ & $2.48 \pm 0.02^{\mathrm{a}}$ & $2.42 \pm 0.04^{\mathrm{a}}$ \\
\hline Progesterone (ng/mL) & $15.61 \pm 0.03^{\mathrm{b}}$ & $14.01 \pm 0.15^{\mathrm{a}}$ & $14.05 \pm 0.22^{a}$ & $14.07 \pm 0.13^{\mathrm{a}}$ & $14.04 \pm 0.12^{\mathrm{a}}$ & $14.06 \pm 0.10^{\mathrm{a}}$ \\
\hline Prolactin $(\mathrm{ng} / \mathrm{mL})$ & $30.25 \pm 0.01^{a}$ & $30.28 \pm 0.06^{\mathrm{a}}$ & $30.33 \pm 0.06^{a}$ & $30.33 \pm 0.06^{a}$ & $30.33 \pm 0.06^{\mathrm{a}}$ & $30.40 \pm 0.06^{\mathrm{b}}$ \\
\hline Estrogen $(\mathrm{pg} / \mathrm{mL})$ & $33.77 \pm 0.18^{\mathrm{a}}$ & $34.17 \pm 0.16^{\mathrm{b}}$ & $34.15 \pm 0.14^{\mathrm{b}}$ & $34.16 \pm 0.14^{\mathrm{b}}$ & $34.16 \pm 0.12^{\mathrm{b}}$ & $34.17 \pm 0.12^{\mathrm{b}}$ \\
\hline Testosterone (ng/dL) & $1.46 \pm 0.00^{\mathrm{b}}$ & $2.67 \pm 0.023^{a}$ & $2.67 \pm 0.06^{\mathrm{a}}$ & $2.67 \pm 0.04^{\mathrm{a}}$ & $2.68 \pm 0.061^{\mathrm{a}}$ & $2.68 \pm 0.038^{a}$ \\
\hline
\end{tabular}

LH: luteinizing hormone; FSH: follicular stimulating hormone; NC: Negative control.

Eryllmaz, 2016). After HT treatment the serum insulin had shown reduction $(\mathrm{p}<0.05)$ in PC1 and PC1.5 as compared to PC0.5, PC2 and PC0. Serum LH levels of PC1.5 and PC2 had shown reduction $(\mathrm{p}<0.05)$ as compared to PC0.5 PC1 and PC0 as presented in Table 3 (Supplementary Material FD1). The serum FSH levels of PC1.5 and PC2 had shown improvement $(\mathrm{p}<0.05)$ as compared to PC0.5, PC1 and PC0. The levels of serum progesterone, estrogen and testosterone in all treatment groups had shown non-significant improvement $(\mathrm{p}>0.05)$ as compared to PC0. The level of serum prolactin in PC2 was significantly increased $(\mathrm{p}<0.05)$ as compared to PC0.5, PC1, PC1.5 and PC0. The possible mechanism might be, when the activity of starch digestive enzymes was inhibited by forming complexes with tannin then these enzymes and HT complex also promoted the hypoglycemia and stimulation of insulin secretion which helped to control insulin resistance. Because in the pathogenesis of PCOS, insulin resistance was considered the major initiative element of oxidative stress (OS) which further contributed to hyper-androgenism (Ghafurniyan et al., 2015). Furthermore, insulin along with LH stimulated the production of high levels of androgens. As the PCOS is a disease of unknown etiology, so the increase in testosterone level was due to the insulin resistance along with increased LH level; obesity and theca cell hyperplasia and OS (Murugesan et al., 2020) so the present results also supported these findings. But the oral administration of different levels of HT decreased the serum insulin, LH and improvement in serum FSH levels in all treated groups. Decreased insulin levels with HT might be due to the extra pancreatic effect of tannin which was independent of insulin as reported previously that the HT had shown insulino-mimetic effects which maintained the antioxidant environment of the pancreatic $\beta$-cells (Sieniawska, 2015) while decreased insulin resistance further helped in the reduction of LH and improvement in FSH hormones. But the treatment with HT had shown no effect to reduce the serum level of testosterone and estrogen and no improvement in serum progesterone which might be due to increased levels of prolactin and short duration of the treatment.

The statistical results of serum total antioxidant capacity (TAC) and total oxidative stress (TOS) of all the PCOS rats fed with different levels of HT are presented in Figure 2 and 3. The serum level of TAC was significantly decreased and TOS was significantly increased $(\mathrm{p}<0.05)$ in $\mathrm{PC} 0$ as compared to $\mathrm{NC}$ (Manzoor et al., 2020). After HT treatment the serum levels of TAC were improved $(\mathrm{p}<0.05)$ in PC1, PC1.5 and PC2 as compared to PC0.5 and PC0 as presented in Figure 2. The serum TOS level of PC1.5 and PC2 had shown a significant decrease $(\mathrm{p}<0.05)$ as compared to PC0.5, PC1 and PC0 as presented in Figure 3. The possible reason was that HT acted as a strong antioxidant (Supplementary Material FD1) which further helped to decrease in TOS and improvement of TAC as also reported previously (Hsu \& Yen, 2007; Manzoor et al., 2020).

The histological examination of the ovaries of PC0 and after dietary intervention with different levels of HT in PC0.5, PC1, PC1.5 and PC2 are presented in Figure 4. In this study, the ovarian histology of the PC0 showed that the exposure of the adult female rats with a single dose of estradiol severely affected the follicular development and reduction in the number of primary, secondary as well as graffian follicles and corpora lutea. The PC0 also showed the development of follicular cysts with 


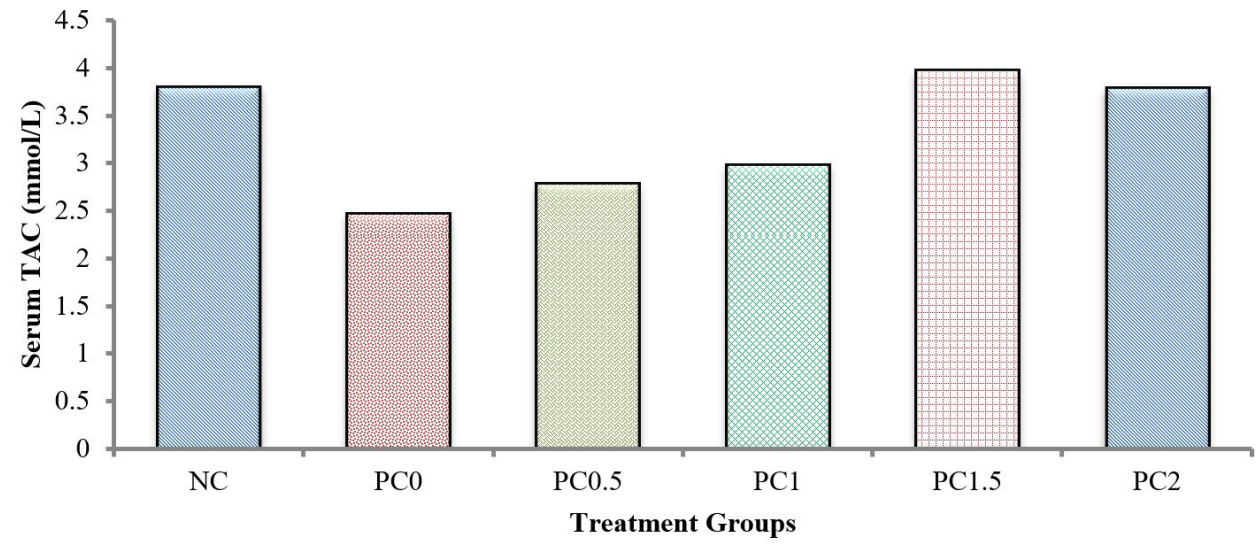

Figure 2. Serum Total Antioxidant Capacity of PCOS Rats.

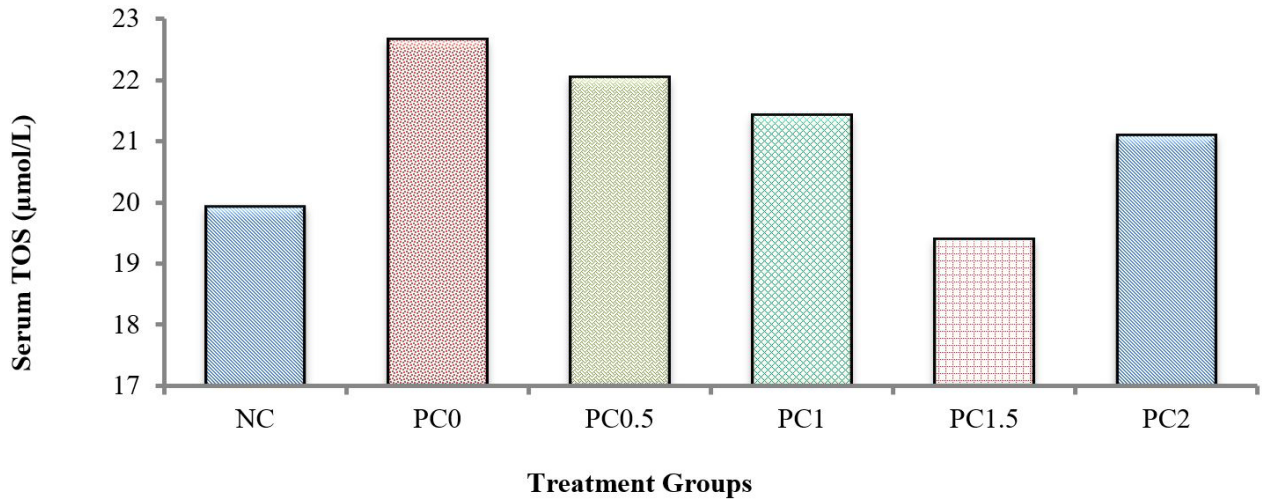

Figure 3. Serum Total Oxidative Stress of PCOS Rats.
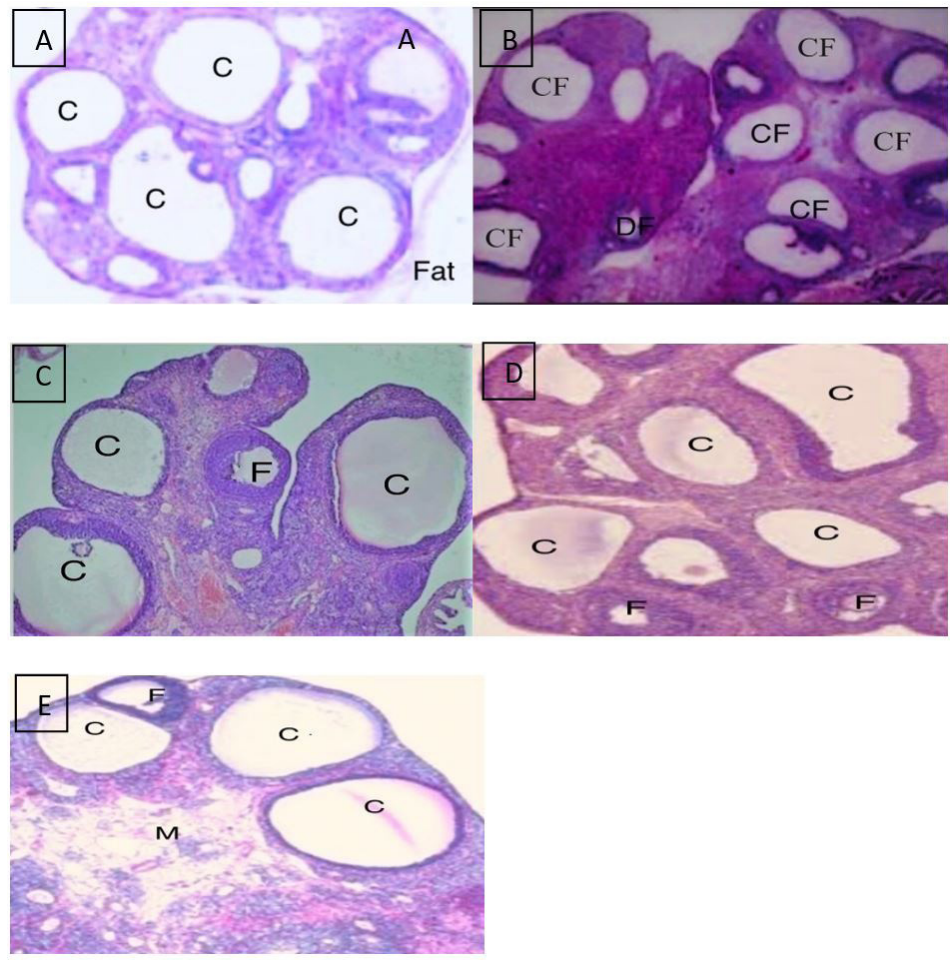

Figure 4. Histopathology of the PCOS Rat's Ovaries. Images A-E shows the different level of tannin intake A: $0 \%$ HT; B: 0.5\% HT; C: $1 \%$ HT; D: $1.5 \%$ HT and E: 2\% HT in PCOS rats. CF: Cystic follicle; DF: Degenerating follicle; C: Cysts; F: Follicle. 
more fatty tissues and follicular atresia as shown in Figure 4A. The ovarian histological evaluation of the PC0.5, PC1, PC1.5 and PC2 had shown the presence of cystic follicles; while no signs of improvement were observed which included the increased number of developing follicles, increased number of corpus luteum (main sign of ovulation) and decreased the number of cystic follicles as shown in Figures $4 \mathrm{~B}$ to $4 \mathrm{E}$. An-ovulation (main reason of infertility) could be due to the increased level of estrogen and testosterone and decreased FSH levels which were confirmed in the present study. As reported previously by Amini et al. (2016), an imbalance of the hormones was impeding the process of folliculogenesis which increased levels of $\mathrm{LH}$ and decreased levels of FSH as confirmed in the present study. The histological examination of ovaries after the treatment with the different levels of HT had shown the presence of the cystic follicles and degenerated follicles, while no increase was observed in the number of developing follicles and corpus luteum (a main sign of ovulation) and any signs of folliculogenesis which might be due to the increased estrogen, testosterone and prolactin levels in all treatment groups. However no signs of ovarian toxicity were observed (Manzoor et al., 2021).

\section{Conclusions}

The dietary intervention with hydrolysable tannin can be an alternate therapy for the treatment of modern diseases, particularly for the oxidative stress associated PCOS. In this study, the $1.5 \%$ level of HT had shown the best results to reduce the body weight, insulin resistance, oxidative stress and improvement in the reproductive hormones LH and FSH. Hence HT had shown the therapeutic potential in PCOS rats. The duration of HT treatment in the present trial was of two months and more encouraging results might be expected if the treatment duration would be more than 3 to 4 months.

\section{References}

Adenike, K. (2013). Effect of processing on the lectin and trypsin inhibitor content of Plukenetia conophora seeds as it affects growth performance and nutrients metabolism in rat. African Journal of Food Science, 7(9), 306-316. http://dx.doi.org/10.5897/AJFS2013.1015.

Amini, L., Tehranian, N., Movahedin, M., Ramezani Tehrani, F., \& Soltanghoraee, H. (2016). Polycystic ovary morphology (PCOM) in Estradiol Valerate treated mouse model. International Journal of Women's Health and Reproduction Sciences, 4(1), 13-17. http:// dx.doi.org/10.15296/ijwhr.2016.04.

Anbu, J., Sukanya, K., Santhosh Kumar, S., Ramya, P., \& Reddy, V. B. N. (2016). Effect of Sargassum ilicifolium on ovogenesis in polycystic ovary syndrome-induced rats. Asian Journal of Pharmaceutical and Clinical Research, 9(6), 127-113. http://dx.doi.org/10.22159/ ajpcr.2016.v9i6.13837.

Andriyas, E. A., \& Lal, S. S. (2013). Impact of oxidative stress on reproductive hormones in fertile and non-fertile females. International Journal of Scientific Research, 438(5), 2319-7064.

Association of Official Analytical Chemists - AOAC. (1990). Official methods of analysis: changes in official methods of analysis made at the annual meeting (Vol. 15). Arlington: AOAC.

Bency Baby, T., Rani, S., Remya, K., Shebina, P., \& Azeem, A. (2016). Polycystic ovarian syndrome: therapeutic potential of herbal remedies: a review. International Journal of Herbal Medicine, 4(5), 91-96.
Bonelli, F., Turini, L., Sarri, G., Serra, A., Buccioni, A., \& Mele, M. (2018). Oral administration of chestnut tannins to reduce the duration of neonatal calf diarrhea. BMC Veterinary Research, 14(1), 227. http:// dx.doi.org/10.1186/s12917-018-1549-2. PMid:30055618.

Bravo, L., Abia, R., Eastwood, M. A., \& Saura-Calixto, F. (1994). Degradation of polyphenols (catechin and tannic acid) in the rat intestinal tract: effect on coloic fermentation and faecal output. British Journal of Nutrition, 71(6), 933-946. http://dx.doi.org/10.1079/ BJN19940197. PMid:8031740.

Bravo, L., Saura-Calixto, S., \& Goni, I. (1992). Effects of dietary fibre and tannins from apple pulp on the composition of faces in rats. British Journal of Nutrition, 67(3), 463-473. http://dx.doi.org/10.1079/ BJN19920051. PMid:1320404.

Buzzini, P., Arapitsas, P., Goretti, M., Branda, E., Turchetti, B., Pinelli, P., Ieri, F., \& Romani, A. (2008). Antimicrobial and antiviral activity of Hydrolysable Tannins. Mini-Reviews in Medicinal Chemistry, 8(12), 1179-1187. http://dx.doi.org/10.2174/138955708786140990. PMid:18855732.

Byers, S. L., Wiles, M. V., Dunn, S. L., \& Taft, R. A. (2012). Mouse estrous cycle identification tool and images. PLoS One, 7(4), e35538. http://dx.doi.org/10.1371/journal.pone.0035538. PMid:22514749.

Carmona, A., Borgudd, L., Borges, G., \& Levy-Benshimol, A. (1996). Effect of black bean tannins on in vitro carbohydrate digestion and absorption. The Journal of Nutritional Biochemistry, 7(8), 445-450. http://dx.doi.org/10.1016/0955-2863(96)00077-0.

Çınar, M., \& Gün Eryılmaz, Ö. (2016). Experimental models of polycystic ovary syndrome. Medeniyet Medical Journa, 31(1), 53-57.

Dalle Zotte, A., \& Elena Cossu, M. (2009). Dietary inclusion of tannin extract from red quebracho trees (Schinopsis spp.) in the rabbit meat production. Italian Journal of Animal Science, 8(2), 784-786. http://dx.doi.org/10.4081/ijas.2009.s2.784.

Dawson, J. M., Buttery, P. J., Jenkins, D., Wood, C. D., \& Gill, M. (1999). Effects of dietary quebracho tannin on nutrient utilisation and tissue metabolism in sheep and rats. Journal of the Science of Food and Agriculture, 79(11), 1423-1430. http://dx.doi.org/10.1002/ (SICI) 1097-0010(199908)79:11<1423::AID-JSFA383>3.0.CO;2-8.

Ekambaram, S. P., Babu, K. B., Perumal, S. S., \& Rajendran, D. (2018). Repeated oral dose toxicity study on hydrolysable tannin rich fraction isolated from fruit pericarps of Terminalia chebula Retz in Wistar albino rats. Regulatory Toxicology and Pharmacology, 92, 182-188. http://dx.doi.org/10.1016/j.yrtph.2017.12.001. PMid:29233773.

Erel, O. (2004). A novel automated direct measurement method for total antioxidant capacity using a new generation, more stable ABTS radical cation. Clinical Biochemistry, 37(4), 277-285. http://dx.doi. org/10.1016/j.clinbiochem.2003.11.015. PMid:15003729.

Erel, O. (2005). A new automated colorimetric method for measuring total oxidant status. Clinical Biochemistry, 38(12), 1103-1111. http:// dx.doi.org/10.1016/j.clinbiochem.2005.08.008. PMid:16214125.

Erhirhie, E., Ekene, N. E., \& Ajaghaku, D. (2014). Guidelines on dosage calculation and stock solution preparation in experimental animals' studies. Journal of Natural Sciencs Research, 4(18), 100-106.

Ghafurniyan, H., Azarnia, M., Nabiuni, M., \& Karimzadeh, L. (2015). The effect of green tea extract on reproductive improvement in estradiol valerate-induced polycystic ovarian syndrome in rat. Iranian Journal of Pharmaceutical Research: IJPR, 14(4), 1215-1233. PMid:26664389.

Ghasemzadeh, A., Farzadi, L., Khaki, A., \& Ahmadi, S. K. (2013). Effect of Allium cepa seeds ethanolic extract on experimental polycystic ovary syndrome (PCOS) apoptosis induced by estradiol-valerate. Life Science Journal, 10(4s), 170-175. 
Hagerman, A. E., Robbins, C. T., Weerasuriya, Y., Wilson, T. C., \& McArthur, C. (1992). Tannin chemistry in relation to digestion. Journal of Range Management, 45(1), 57. http://dx.doi.org/10.2307/4002526.

Hsu, C.-L., \& Yen, G.-C. (2007). Effect of gallic acid on high fat dietinduced dyslipidaemia, hepatosteatosis and oxidative stress in rats. British Journal of Nutrition, 98(4), 727-735. http://dx.doi.org/10.1017/ S000711450774686X. PMid:17475086.

Kimber, O., Cromley, J. G., \& Molnar-Kimber, K. L. (2018). Let your ideas flow: Using flowcharts to convey methods and implications of the results in laboratory exercises, articles, posters, and slide presentations. Journal of Microbiology \& Biology Education, 19(1), http://dx.doi.org/10.1128/jmbe.v19i1.1477 PMid:29904528.

Manzoor, F., Nisa, M. U., Hussain, H. A., Ahmad, N., \& Umbreen, H. (2020). Effect of different levels of hydrolysable tannin intake on the reproductive hormones and serum biochemical indices in healthy female rats. Scientific Reports, 10(1), 20600. http://dx.doi. org/10.1038/s41598-020-77672-0. PMid:33244120.

Manzoor, F., Nisa, M. U., Hussain, H. A., Ahmad, N., \& Umbreen, H. (2021). Effect of chestnut hydrolysable tannin on weight management and ovarian histopathology of healthy female rats. The Journal of Animal and Plant Sciences, 31(3), 831-840.

Murugesan, B. M., Muralidharan, P., \& Hari, R. (2020). Effect of ethanolic seed extract of Caesalpiniabonducella on hormones in mifepristone induced PCOS rats. Journal of Applied Pharmaceutical Science, 10(2), 72-76. http://dx.doi.org/10.7324/JAPS.2020.102012.

National Research Council. (1995). Nutrient requirements of laboratory animals. Washington: National Academies Press.

Nofal, E. A., El-Habeby, M. M., El-Kholy, W. B., El-Akabawy, G. F., \& Faried, M. A. (2019). Protective role of Broccoli extract on estradiol valerate-induced polycystic ovary syndrome in female rats. Europian Journal of Anatomy, 23(2), 121-129.

Ramachandran, S., Nikitha, J., Gopi, C., Amala, M., \& Dhanaraju, M. D. (2020). Effect of prunus dulcis and salvia hispenica in the management of polycystic ovary syndrome in Wistar rats. Journal of Taibah University Medical Sciences, 15(2), 122-128. http://dx.doi. org/10.1016/j.jtumed.2020.02.002. PMid:32368208.

Reeves, P. G., Nielsen, F. H., \& Fahey, G. C. Jr. (1993). AIN-93 purified diets for laboratory rodents: final report of the American Institute of Nutrition ad hoc writing committee on the reformulation of the AIN-76A rodent diet. The Journal of Nutrition, 123(11), 1939-1951. http://dx.doi.org/10.1093/jn/123.11.1939. PMid:8229312.
Roychoudhury, S., Agarwal, A., Virk, G., \& Cho, C.-L. (2017). Potential role of green tea catechinsin the management of oxidative stressassociated infertility. Reproductive Biomedicine Online, 34(5), 487498. http://dx.doi.org/10.1016/j.rbmo.2017.02.006. PMid:28285951.

Sadoughi, S., Rahbarian, R., Jahani, N., Shazdeh, S., Hossein Zadeh Saljoughi, S., \& Daee, M. (2017). Effect of aqueous extract of Artemisia absinthium L on sex hormones, inflammatory cytokines and oxidative stress indices of ovarian tissue in polycystic ovary syndrome rat model. Majallah-i Danishgah-i Ulum-i Pizishki-i Babul, 19(7), 50-56.

Sharma, R., Goyal, A., \& Bhat, R. (2013). Antifertility activity of plants extracts on female reproduction: A review. International Journal of Pharma and Bio Sciences, 3(3), 493-514.

Shi, H., Li, S., Cao, Z., Wang, Y., Alugongo, G., \& Doane, P. (2015). Effects of replacing wild rye, corn silage, or corn grain with $\mathrm{CaO}$-treated corn stover and dried distillers grains with solubles in lactating cow diets on performance, digestibility, and profitability. Journal of Dairy Science, 98(10), 7183-7193. http://dx.doi.org/10.3168/ jds.2014-9273. PMid:26210280.

Sieniawska, E. (2015). Activities of tannins: from in vitro studies to clinical trials. Natural Product Communications, 10(11), 1877-1884. http://dx.doi.org/10.1177/1934578X1501001118. PMid:26749816.

Silverman, J., Suckow, M. A., \& Murthy, S. (2014). Origins of the IACUC. In J. Silverman, M. A. Suckow \& S. Murthy (Eds.), The IACUChandbook (pp. 22-31). Boca Raton: CRC Press. http://dx.doi. org/10.1201/b17109-7.

Slaoui, M., \& Fiette, L. (2011). Histopathology procedures: from tissue sampling to histopathological evaluation. In J. C. Gautier (Ed.), Drug safety evaluation methods and protocols (pp. 69-82). Switzerland: Springer. http://dx.doi.org/10.1007/978-1-60761-849-2_4.

Velayutham, R., Sankaradoss, N., \& Ahamed, K. N. (2012). Protective effect of tannins from Ficus racemosa in hypercholesterolemia and diabetes induced vascular tissue damage in rats. Asian Pacific Journal of Tropical Medicine, 5(5), 367-373. http://dx.doi.org/10.1016/S19957645(12)60061-3. PMid:22546653.

Zhai, H.-L., Wu, H., Xu, H., Weng, P., Xia, F.-Z., Chen, Y., \& Lu, Y.-L. (2012). Trace glucose and lipid metabolism in high androgen and high-fat diet induced polycystic ovary syndrome rats. Reproductive Biology and Endocrinology, 10(1), 5. http://dx.doi.org/10.1186/14777827-10-5. PMid:22276997. 
Original Article

Hydrolysable Tannin: Weight Management and Reproductive Health in Polycystic Rats

Supplementary Material (FD1) (Kimber et al., 2018)

Supplementary material accompanies this paper.

Flow Diagram

This material is available as part of the online article from http://www.scielo.br/cta 